\title{
Assessing the Impact of Pro-Environmental Factors on Sustainable Gasoline Consumption and Pollution Control by Saudi Arabian Residents
}

Sania Khan ( $\nabla$ saniakhan05@gmail.com )

Prince Sattam bin Abdulaziz University College of Business Administration https://orcid.org/00000003-3072-8310

\section{Research Article}

Keywords: Pro-Environmental factors, Pollution Control, Sustainable consumption, Saudi residents, Gasoline

Posted Date: January 25th, 2022

DOI: https://doi.org/10.21203/rs.3.rs-1168777/v1

License: (a) (i) This work is licensed under a Creative Commons Attribution 4.0 International License. Read Full License 


\section{Abstract}

Saudi Arabia is one of the most oil-rich countries in the world, and oil production is the country's primary source of income. The aspects of greenhouse gas emissions and the harm they cause to the environment and residents were overlooked because of the continuous emphasis on economic growth and a high reliance on oil resources. Consequently, the environmental issues have become challenging for residents and questionable for industries. Despite various environmental awareness and pollution control studies around the world, Saudi Arabia's pollution rate appears to be increasing. The study attempted to understand the impact of pro-environmental factors on pollution control and sustainable gasoline consumption in order to fill a research gap in the literature. Environmental awareness, self-efficacy and self-identity, ecological attitude, contextual factors, and social norms were considered as factors to investigate local residents' sustainable consumption and pollution control behaviour. The primary data was collected from 216 local residents and analyzed using multiple regression. The results demonstrated the positive significant impact of pro-environmental variables on sustainable consumption and efforts to pollution control. The study further presents practical implications for the Saudi government and environmentalists.

\section{Introduction}

Technology has advanced so much in exploring oil wells and producing them. Johnston et al., 2019 stated there will be a partial or full adverse effect on the overall environment. Though the positive sides of oil production increase the national income and infrastructure, the negative side of its production pollutes the air, soil and water. Therefore, the positive aspects are constantly focused on oil production, ignoring the environmental issues. Many studies have reported the release of greenhouse gases (GHGs) with $\mathrm{CO}_{2}$ as the major polluting component and subsequent health issues for mankind (EPA, 2019; Bekum et al., 2019; Johnston et al., 2019; Roberts et al., 2019). However, Saudi Arabia lacks such studies. While Middle Eastern countries are rich in oil reserves, Saudi Arabia has been considered to be the highest producing country in the world since the 1930s (Nasir et al., 2019). During the 1980s, Middle East countries used to produce only 11 million barrels per day and 15 million barrels in the 1990s, and further increased their production capacity to 18 million barrels per day in the twenty-first century, with Saudi Arabia as the major contributor. With the realization of the increase in huge carbon emissions, Saudi Arabia executed green initiatives by establishing renewable sources for generating renewable and nuclear energy of up to 50 giga watts (GW). Also, the latest price reforms on oil have enabled a reduction in oil consumption and pollution control (KAPSARC, 2019). Gonand et al., 2019 assumed the increase in local oil prices would improve the environment and reduce local oil consumption by promoting the local welfare of society and reinforcing oil exports. The strategic aim of the Saudi government towards the 2030 vision is to maintain low water, soil, air and sound pollution (Government of Saudi Arabia, 2019).

Since 2009, the increase in consumption of oil resources has been increasing, and in 2018 it was the lowest consumption of barrels per day. Due to extreme climatic conditions, reaching 50 degrees Celsius during summer and falling below 0 degrees Celsius in some regions during winter. So, to meet the cooling 
requirements through air conditioners, most of the consumption of crude oil was predominantly used for the production of electricity and the next largest consumer was the road transportation sector (MEP, 2015a). So power consumption has elevated by tenfold during the last few decades, but the demand for gasoline in road transportation has raised from 25 million barrels to 204 million barrels in 2015, which is on an average of 6 percent per annum ((MEP, 2015a). The central department of statistics and information (CDSI), expected population growth of roughly 30 million residents, which accounted for a $2.6 \%$ increase in 2014 , and this may further upsurge the demand for gasoline for residents to commute inside the country. So there is a potential growth in gasoline products with the increase in the population and consequently intensifying carbon emissions. As the controversial, awareness of environmental issues and consumption patterns are below the expected level among the Saudi population. Also, it is essential to conduct scientific studies in the Saudi Arabia context on awareness of climate change, its adverse effect on the ecosystem, and sustainability. Therefore, there is an immense need to create a positive attitude towards environmental protection and sustainable consumption. Therefore, this research study is projected to understand the role of environmental factors and the commitment of Saudi residents to pollution control and sustainable consumption of gasoline products which are used in daily life.

\section{Literature Review}

Saudi Arabia's economic growth steadily increased after identifying the oil sources and oil production. Though the extant literature explains the adverse impact of oil production and consumption patterns on ecological development, there is a significant amount of ignorance among consumers about proenvironmental behaviour and adherence to sustainable consumption patterns. Therefore, the literature is presented in two folds. Firstly, it will expose the crude oil consumption patterns and gasoline demand and pricing policies in the last decades. Secondly, it presents the theoretical aspects of pro-environmental behaviour that drive consumers to sustainable consumption and pollution control.

\section{Crude oil consumption pattern in Saudi Arabia}

Among the countries in the world, Saudi Arabia is one of the geographical locations which faces extreme hot climatic conditions in Saudi Arabia. Especially during summer, there is a high demand for electricity consumption among industries and residents due to the increase in use of air conditioning systems. According to the joint organizations data initiative (JODI), the nation burned a huge amount of crude oil, 0.9 million barrels per day during the month of July. It has been recorded as the highest consumption of crude oil since August 2010. In comparison, the consumption of crude oil from 2009 to 2013 for power generation was 0.7 million barrels per day. During the same period, other Middle East countries like Kuwait and Iraq ranked first and second in crude oil consumption, with approximately 0.08 million barrels per day. While most countries depend on consuming natural gas or coal for electricity production, the nation suffers from the non-availability of local coal production. On the other hand, it lacks such natural gas production operations due to the large amount of sulfur content in natural gas and the low price of domestic natural gas. Hence, foreign direct investments (FDI) found no more lucrative investments in 
natural gas ventures (Rebecca George, 2014). During the same decade, in 2012, the total electricity consumption has doubled since 2000 , to roughly 232 billion KWh. However, this did not pause the nation's economic growth. Rather, it boosted to $4.7 \%$ in 2014 from 3.8\% in 2013. The central department of statistics and information (CDSI), predicted the growth of the population at roughly 30 million inhabitants, accounting for a $2.6 \%$ increase in 2014 , which may still hike the electricity demand (Rebecca George, 2014). The sustainable initiative taken by the Saudi government focused on diversifying the sources of power generation and adopted more energy-efficient methods to increase the capacity of generating 58 gigawatts (GW) to 120 GW by 2032 using renewable energy sources like solar and nuclear power. This approach reduces the dependability of crude oil except for producing more diesel (U.S. Energy Information Administration, 2014).

Despite the objective of reducing crude oil consumption, the highest record of burning crude oil for power generation was again seen in 2015, with 0.9 million barrels per day. However, as committed, Saudi Arabia achieved a controlled consumption of less crude oil in 2018 for electricity generation on an average of 0.4 million barrels per day, which was in fact much less than in 2009. This was because of the parallel use of fuel oil and natural gases. The comparative usage of crude oil for power generation from 2009-2014 and 2013-2018 is illustrated in figure 1. Natural gases are produced in association with the wells of crude oil production, though these wells are not connected with regular oil production. Hence, the consumption of natural gases also apparently increased (Rebecca and Emily, 2019). Figure 2 shows the comparative consumption of both oil and natural gases.

\section{Gasoline Demand and Pricing Policy}

During the last few decades, the consumption of gasoline increased by 6 percent per annum and the consumption per capita is derived from the ratio of total gasoline consumption by the population in the country.

\section{Gasoline consumption per capita $=$ Gasoline consumption/Population in KSA}

From 2010 to 2018, the consumption increased from 2.44 liters per capita to 3.07 liters per capita. The below Table 1 illustrates more details of the indicators during the respective years. In 2015, the Saudi government increased the price of water, fuel and electricity for domestic consumption, and the price of gasoline for 91 octane grade increased from SAR 0.45 to SAR 0.60 and for 95 octane grade from SAR 0.75 to SAR 0.90 (Tarek N. Atalla et al., 2018). However, the price has changed multiple times during the course of time, and the current rate in the year 2021 for 91 and 95 octane grades is SAR 2.18 and SAR 2.33 respectively. Due to the increase in prices, the estimation of demand and supply curves demonstrated the improvement in social welfare would be approximately SAR 1 to 2 billion per annum in 2010 , which amounts to 0.1 percent of GDP in 2015. There are no exact studies which measured the amount of carbon emissions in relation to the amount of gasoline consumption. The study, conducted by Alkhathlan and Javid (2015), attempted to evaluate the impact of total oil consumption and transportation on Saudi Arabia's environment. But the estimation of carbon emissions from the 
underlying energy demand trend (UEDT) and the transportation sector did not consider the gasoline demand nor the price and income variations.

Table 1

Per Capita Consumption of Gasoline 2010-2018 (Source: General Authority for Statistics)

\begin{tabular}{|c|c|c|c|}
\hline \multirow[t]{4}{*}{ Years } & \multicolumn{3}{|l|}{ Indicator } \\
\hline & $\begin{array}{l}\text { Gasoline } \\
\text { consumption }\end{array}$ & $\begin{array}{l}\text { The population in Saudi } \\
\text { Arabia }\end{array}$ & $\begin{array}{l}\text { Consumption of Gasoline per } \\
\text { Capita }\end{array}$ \\
\hline & \multicolumn{3}{|l|}{ unit } \\
\hline & Thousand tons & Number & Litre per capita \\
\hline 2010 & 18,114 & $27,410,510$ & 2.44 \\
\hline 2011 & 19,172 & $28,173,195$ & 2.52 \\
\hline 2012 & 20,783 & $28,896,842$ & 2.65 \\
\hline 2013 & 21,702 & $29,613,068$ & 2.71 \\
\hline 2014 & 22,659 & $30,339,797$ & 2.76 \\
\hline 2015 & 24,355 & $31,062,072$ & 2.90 \\
\hline 2016 & 29,032 & $31,787,580$ & 3.37 \\
\hline 2017 & 29,694 & $32,612,846$ & 3.37 \\
\hline 2018 & 27,765 & $33,413,660$ & 3.07 \\
\hline
\end{tabular}

\section{Antecedents of Pro-Environmental Consumer Behaviour}

Following the late 1960s ecological activism, environmental concerns began to play an increasing role in anti-sprawl critiques. According to this school of thought, moderate settlement led to substantial energy consumption, particularly through automobile access. This, in turn, tends to result in resource depletion and increased pollution. Reduced settlement also resulted in a loss of grassland, elevated health issues among citizens, and ozone layer depletion. Attempts to spread environmentally friendly consumption are frequently grouped under the umbrella term "sustainability". Evidently, energy consumption in Arab countries is significantly greater. Many ecologists believe that this is a universal human challenge which can only be overcome through strict mitigation measures and metropolis redesign to be more energyefficient. The huge usage of personal vehicles is the most acrimonious area involving both gasoline consumption and the emission of carbon footprints as well (Alzubaidi et al., 2021; Bhuian et al., 2018; Delistavrou et al., 2021).

Various influencing factors have been identified in research studies on understanding consumer behavior and sustainable consumption. The majority of these studies found that pro-environmental factors influenced consumers' attitudes toward sustainable consumption and pollution control. Some of these 
pro-environmental behavior factors were also presented in the theory of planned behavior (TPB). For example, social norms were defined as consumer expectations from a group of individuals about a specific behavior and as a foundation for how he chooses to adopt his behavior and attitude in relation to the social context. The personal norm is the moral commitment of the consumer to behave ecologically in a given situation. Similarly, consumer attitudes towards the environment were discussed in multiple research studies (Janmaimool et al., 2016; De Groot and Steg 2009; Steg. et al 2014; Schwartz, 2012).

\section{Environmental Awareness}

As stated by Roy, (2013), environmental consciousness and awareness are related to cognitive factors which comprise knowledge, memory, thinking and mitigation of problems. Consumers' responsibility for universal ecological condition and the desire to improve it are also associated with this factor. The greater their awareness, the more they are engaged with sustainable consumption (Quoquab and Mohammad, 2020; Beniulyte et al., 2020; Mazzoni, 2020; Cheng and Wu, 2015). Kullmuss and Agyeman (2002) illustrated the difference between ecological knowledge about facts and their actions. Information about facts is about environmental problems and their causes and consequences; and information about actions is associated with environmentally friendly consumption. This statement was also statistically validated by Tanner and Kast (2003). Based on this concept, it is hypothesized as below.

Hypothesis $1(\mathrm{H} 1)$ : Consumer environmental awareness has a positive significant influence on sustainable consumption.

\section{Self-efficacy and Self-identity}

The construct of self-efficacy is the ability of the consumer to engage in a prospective situation, get motivated, and rectify his actions while facing challenges. Such individuals feel their contribution may help solve global problems (Huang, 2016). Janmaimool et al., 2016 also asserted that self-efficacy encourages pro-environmental engagement and sustainable consumption. On the other hand, selfidentity is characterized by what an individual believes about himself in the context of being environmentally conscious. Such consumers were found to behave sustainably and tend to have sustainable transportation (Van Der Weriff et al., 2013). It is evident that pro-environmental self-identity has a positive significant effect on sustainable consumption. Therefore, it is hypothesized as below.

Hypothesis (H2): Consumer pro-environmental self-efficacy and self-identity have a positive significant influence on sustainable consumption.

\section{Ecological Attitude}

It is associated with consumers who are positive and concerned about environmental protection in all aspects of their lives, as well as with optimistic and pessimistic opinions and responses to individuals, objects, and circumstances (Ugulu et al., 2013). Various other key components, like environmental 
perception, personal norms, values, and the connection to place are included in this factor (Janmaimool and Denpaiboon, 2016; Ali et al., 2019). As stated by (Schwartz, 2012), there are two types of consumer values: self-transcendence and self-enhancement. Self-transcendence consumers are those who are strongly inspired by qualities such as social responsibility, open-mindedness, advisableness, and truth; self-enhancement consumers are those who are concerned about society and devote less time to selfneeds. Personal norms, as a sub-factor of ecological attitude, influence consumers' pro-environmental behavior and promote environmentally friendly consumption (Doran and Larsen 2015; Onel 2016; Hidaya and Agustin, 2017; Bouman and Steg, 2019) demonstrated a positive relationship between personal norms and pro-environmental behavior during sustainable consumption. Connection to place is correlated with better emotional reactions, and such consumers are more inclined to protect the environment around them and promote ecological consumption. (Chanchaichujit et al., 2018). Hence, it is hypothesized as below.

Hypothesis $3(\mathrm{H} 3)$ : Consumers' ecological attitude have a positive significant influence on sustainable consumption.

\section{Contextual factors}

These are the external factors which influence consumers' sustainable consumption. Such conditions exist during the purchase, use, and disposing of goods and services (Geiger et al., 2018). In this context, (Wang et al., 2014) investigated consumers' decisions to use public transportation and waste water treatment; (Maki et al., 2019) examined energy conservation behavior and stated that the prices of various commodities and services are associated with positive and negative thoughts concerning sustainable consumption. Therefore, consumers adjust their behavior according to the situation. Therefore, it is hypothesized as below.

Hypothesis $4(\mathrm{H} 4)$ : Contextual factors have no significant influence on sustainable consumption.

\section{Social Norms}

These norms include common beliefs, basic rules, and perspectives of society, as well as acceptance of a particular behavior by an individual and the public in general (Ture and Ganesh, 2014). When consumers are new and have little experience with certain goods and services, this factor has a strong influence. Such behavior is commonly seen among family members and relatives. So it is hypothesized as below.

Hypothesis 5 (H5): Social norms have a positive significant influence on sustainable consumption.

\section{Sustainable Consumption and Pollution Control}


Sustainable consumption refers to people committing to using minimum products, services, and natural resources in order to live a quality lifestyle while also protecting the environment by reducing toxic substances, carbon emissions, and other pollutants. It also emphasizes meeting current needs while also sustaining future needs. As reported by the OECD studies, there is a significant difference in sustainable consumption patterns by age. Young people realize their consumption patterns have an adverse impact on society and the environment. They are found to be more ecologically conscious in reducing pollution and contributing to the development of human health (UNEP/UNESCO, 2001). According to a study conducted by Parry et al. (2014), including the gasoline consumption pattern of Saudi Arabia, the price inflation in gasoline minimizes the gasoline consumption of passengers and considers the overall travel distance travelled by them. This approach also assists in putting down hazardous gas emissions, air pollution, and reduces road accidents and congestion. Based on this, it is hypothesized as below.

Hypothesis 6 (H6): Sustainable consumption Environmental awareness has a positive significant influence on sustainable consumption.

The framework of the study is conceptualized as shown in below figure 3 .

\section{Research Methodology}

This study employed a self-administered questionnaire with closed-ended questions. For the constructed items, questions were developed on a 5-point Likert scale for the study, 5 as strongly agree, 4 as agree, 3 as neutral, 2 as disagree and 1 as strongly disagree. Simple random sampling method has been used to distribute the questionnaire using an online mode by emails and sharing the link of google form among the male and female residents of Saudi Arabia within the age group of 20 to 50 years who employed and salaried in public or private organization and commute by their own automobile. The simple random sampling method gives an equal opportunity for all the individuals in the population having equal chance of being selected for the sample. The questionnaire yielded a total of 216 valid responses, which were analyzed further in SPSS using multiple regression.

\section{Results And Discussions}

The study used multiple regression analysis to explore the underlying dimensions of the proenvironmental, sustainable consumption and pollution control constructs and further tested the formulated hypotheses. The below Table 2 demonstrates the mean, factor loadings and reliability condition of the collected data. To determine the underlying dimensions, the exploratory factor analysis (EFA) method with principal component analysis (PCA) under varimax rotation was used and revealed the acceptable condition of all the factor loadings, which are above 0.6. The factor loadings of EA are from 0.790 to 0.981 with alpha value 0.806 ; for SEl from 0.765 to 0.874 and alpha value 0.841 ; for EAT from 0.802 to 0.900 and alpha value 0.748 ; for CF from 0.769 to 0.938 and alpha value 0.782 ; for SN 0.850 to 0.900 and alpha value 0.841 ; for 0.771 to 0.882 and alpha value 0.943 ; for PC 0.974 to 0.980 and alpha value 0.0 .854 respectively. Also, the internal consistency (Cronbach alpha value) are all in a tolerable 
range of above 0.7 and verified the reliability condition (Nunnally, 1978). The factorability conditions were also confirmed by the Kaiser-Meyer-Olkin value of 0.832 and a significant Bartlett's test of sphericity ( $p$ $<0.001)$. 
Table 2

Mean, factor loadings and reliability values of pro-environmental behaviour towards automobiles' sustainable gasoline consumption and pollution control

(Source: Author)

\section{Dimensions \& Items}

Environmental Awareness (EA)

- I am aware that my use of automobiles will result in carbon footprints and environmental pollution (EA1).

-I believe it is ones' responsibility to put down excessive consumption of gasoline for controlling pollution (EA2).

- I recall my ecological knowledge while driving and strictly adhere to sustainable gasoline consumption (EA3).

- My environmental actions are reflective of my ecological knowledge (EA4).

Self-efficacy \& Self-identity (SEI)

- I engage a lot of time thinking about how much damage overconsumption causes to the environment that we live in (SEI1).

- I travel only when necessary and forego my pleasures to contribute to a better environment (SEI2).

- I believe I am consuming fewer gasoline products and promote sustainable transportation(SEI3).

- During my holidays, I stay at home and give up the pleasure of visiting places to practice sustainable consumption (SEI4).

Ecological Attitude

- I care to buy environmentally friendly automobiles (EAT1).

- I am a socially responsible individual who is eager to educate others about the environmental impact of gasoline products (EAT2).

-A pollution-free atmosphere motivates me to sustain the future environment (EAT3)

- Since I care about the environment, I take a shared car to work (EAT4).

Contextual Factors (CF)

3.14

0.782

- I am willing to pay a high price for environmentally friendly automobiles (CF1).
2.81

0.748

\section{Mean Factor Cronbach \\ Loading Alpha \\ Value}

3.59

0.806

0.875

0.981

0.802

0.790

2.79

0.841

0.874

0.831

0.870

0.765

0.900

0.886

0.802

0.877 
Factor

Cronbach

Loading

Alpha

Value

- I am willing to use public transportation because I want to live a low-carbon lifestyle (CF2).

0.769

- I believe that the recent constant increase in gasoline prices will

have a positive impact on Saudi residents' sustainable

consumption (CF3).

- Travelling by own car is much cheaper and more comfortable for

me than taking public transportation (CF4).

Social Norms (SN)

2.83

0.841

- I have recommended my family, friend, and colleagues at work not

to buy some automobiles which emit high carbon pollutants (SN1).

-When I buy a new car, I ask my friends for advice on the mileage (SN2).

- There is frequent public transportation in Saudi Arabia, such as metro trains and national buses that connect to various locations (SN3).

Sustainable Consumption (SC)

- I choose automobiles that are non-polluting and friendly to the environment SC1).

- I understand the true meaning of sustainability and practice environmentally friendly usage of gasoline vehicles (SC2).

- I am pleased when my own gasoline consumption choices contribute to pollution control (SC3).

Pollution Control (PC)

- I believe in practicing sustainable consumption, and the same can contribute to pollution control (PC1)

- Even in the future, with the proportionate rise in the size of Saudi residents, the overall pollution from gasoline can be controlled through sustainable consumption (PC2).
0.880

0.860

0.900

0.850
3.27

0.943

0.882

0.771

0.880

2.75

0.974

0.980

The results of multiple regression are shown in Tables 3, 4, 5 and 6 . The summary of regression analysis toward sustainable consumption of gasoline automobiles is shown in Table 3. According to the regression model, $R$ square is 0.985 , indicating that 98.5 percent of the factor variance contributes to sustainable consumption. 
Table 3

Model summary of SC

(Source: Author)

\begin{tabular}{|llllll|}
\hline Model & $\mathbf{R}$ & $\mathbf{R}^{2}$ & Adjusted $\mathbf{R}^{2}$ & $\mathbf{F}$ & Sig \\
\hline 1 & $0.985^{\mathrm{a}}$ & 0.970 & 0.969 & 1053.508 & 0.000 \\
\hline & $* R^{2}=$ Coefficient of regression, $R=$ Regression value, $F=$ degree of freedom, sig= significance \\
\hline
\end{tabular}

Table 4 represents the regression model coefficients, which show that the independent variables EA, SEl, EAT, CF, and SN are significant and explain Saudi residents' sustainable consumption. $\mathrm{H} 1, \mathrm{H} 2, \mathrm{H} 3, \mathrm{H} 4$, and H5 are supported based on these findings. It is also clear that self-efficacy and self-identity have the least influence on sustainable consumption, while ecological attitudes have the most influence. Hence, it is widely assumed that the residents possess a good attitude towards the environment. However, it is observed that the recent increase in gasoline prices has pushed residents toward more environmentally friendly consumption.

Table 4

Coefficients - model summary of SC (Dependent Variable: SC)

(Source: Author)

\begin{tabular}{|llllll|}
\hline Model & $\begin{array}{l}\text { Unstandardised } \\
\text { Coefficients }\end{array}$ & & Standardised Coefficients & $\mathbf{t}$ & Sig. \\
\hline & $\boldsymbol{\beta}$ & $\begin{array}{l}\text { Std. } \\
\text { error }\end{array}$ & Beta & & \\
\hline (Constant) & 9.501 & 1.985 & & 3.851 & 0.005 \\
\hline EA & 0.795 & 0.179 & 0.261 & 2.574 & 0.035 \\
\hline SEl & 0.204 & 0.049 & 0.254 & 4.152 & 0.000 \\
EAT & 0.617 & 0.135 & 0.697 & 4.566 & 0.000 \\
\hline CF & 0.319 & 0.057 & 0.377 & 5.561 & 0.000 \\
\hline SN & 0.341 & 0.113 & 0.436 & 3.007 & 0.003 \\
\hline$* \beta=$ beta, $t=t$-test value, sig= significance & & & & \\
\hline
\end{tabular}

The summary of regression analysis toward pollution control is shown in Table 5. According to the regression model, $\mathrm{R}$ square is 0.888 , indicating that 88.8 percent of the factor variance contributes to pollution control. Table 6 represents the regression model coefficients of PC and demonstrates that the independent variable SC has a significant influence on PCs and explains Saudi residents' sustainable consumption, leading to pollution control. Hence, $\mathrm{H} 6$ is supported. 
Table 5

Model Summary of PC (Constant: SC)

(Source: Author)

\begin{tabular}{|c|c|c|c|c|c|}
\hline Model & $\mathbf{R}$ & $\mathrm{R}^{2}$ & Adjusted-R ${ }^{2}$ & $F$ & Sig \\
\hline 1 & $0.888^{a}$ & 0.789 & 0.787 & 619.814 & 0.000 \\
\hline
\end{tabular}

Table 6

Coefficients - model summary of PC (Dependent Variable: PC)

(Source: Author)

\begin{tabular}{|llllll|}
\hline Model & \multicolumn{2}{l}{ Unstandardised Coefficients } & \multicolumn{3}{l|}{ Standardised Coefficients } \\
\hline & $\boldsymbol{\beta}$ & Std. error & $\boldsymbol{\beta}$ & $\mathbf{t}$ & Sig. \\
\hline (Constant) & 0.651 & 0.086 & & 7.593 & 0.000 \\
SC & 0.639 & 0.026 & 0.888 & 24.896 & 0.000 \\
\hline \multirow{2}{*}{$\boldsymbol{*}$ = beta, $t=$ t-test value, sig= significance } & & & \\
\hline
\end{tabular}

\section{Conclusion}

The purpose of this study was to assess the pro-environmental behavior of Saudi residents in terms of their sustainable consumption of gasoline through the use of automobiles and its effect on pollution control. The study demonstrated a positive influence of pro-environmental behavioural factors on sustainable consumption and a further significant impact on pollution control. However, the measures of the constructs revealed that the residents' actions are not so strongly reflective of their ecological knowledge. Most respondents agreed that they travel by car when necessary rather than taking public transportation because public transportation such as metro trains and buses is not frequently connected to their destination. In addition, they feel more at ease and save money when they travel in their own vehicles. They are more influenced by environmental attitudes when purchasing new automobiles. They may also change their minds based on other factors, namely cost, comfort, necessity, and location. Though the relationship between the independent variables and the dependent variables is significant, it is assumed that such behavior has recently been observed following the increase in gasoline prices. Such fluctuating gasoline consumption patterns and reduction in pollution were also commonly noted by past researchers both within Saudi Arabia and other countries (Rebecca George, 2014; Kagawa et al., 2012).

However, the extent to which consumers' gasoline consumption shifts to a more sustainable level cannot be determined solely by examining pro-environmental behavior and attitudes. It is more important to focus on many other aspects of genuine intentions that drive sustainable or ecological actions, such as the degree to which this shift in models and types of cars used by consumers, the annual average 
distance travelled by standard-sized cars, the transition from old models to new eco-friendly automobiles, and the implications of shifting between various automobile models. Furthermore, the study made no attempt to understand whether the reduction in pollution and improvement in fuel consumption were the result of a reduction in fuel consumption or a decrease in the annual average travel distance. Also, the study made no specific attempt to investigate other modes of gasoline consumption, such as consumption of diesel by daily logistics for commercial purposes, households, etc. Furthermore, the results are based on the respondents' ecological knowledge and attitudes toward sustainable consumption. The real intentions leading to their actual actions were not investigated. So, additional studies with a larger sample size are required to confirm the findings of this study along with other means of gasoline consumption patterns.

As a result, before expecting any sustainable consumption of gasoline or efforts to reduce pollution control, the government must provide adequate public transportation at an affordable cost to the citizens and residents. Furthermore, the government can use a few tools, like ecological awareness campaigns, subsidies and taxes, environmental standards, and stringent regulations to use light gasoline-powered vehicles to encourage residents to consume gasoline in a more sustainable manner and to reduce pollution.

\section{Declarations}

\section{Acknowledgments}

The author thanks to all the respondents who made this possible.

\section{Consent to Publish}

The author(s) do not have any consent to publish this research paper.

\section{Authors Contributions}

The corresponding author has conducted conceptualization, literature search, original draft editing, reviewed the manuscript, and critically revised the work.

designed and analysed the article

\section{Funding}

The authors declare that no funds, grants, or other support were received during the preparation of this manuscript.

\section{Competing Interests}

The authors declare no competing interests. 
Availability of data and materials

Not applicable

\section{Compliance with ethical standards}

Ethical approval This article does not contain any study with human and animals performed by any of the author

Consent to participate Not applicable.

Consent to publish Not applicable.

Competing interests The authors declare that they have no conflict of interest.

\section{References}

1. Ajzen I (1985) From intentions to actions: A theory of planned behavior. In Action Control; Kuhl, J., Beckmann, J., Eds.; Springer: Berlin/Heidelberg, Germany, ; pp. 11-39

2. Ali A, Xiaoling G, Ali A, Sherwani M, Muneeb FM (2019) Customer motivations for sustainable consumption: Investigating the drivers of purchase behavior for a green-luxury car. Bus Strat Environ 28:833-846. https://doi.org/10.1002/bse.2284

3. Alkhathlan K, Javid M (2015) Carbon emissions and oil consumption in Saudi Arabia. Renew Sustain Energy Rev 48:105-111)

4. Alzubaidi H, Slade EL, Dwivedi YK (2021) Examining antecedents of consumers' pro-environmental behaviours: TPB extended with materialism and innovativeness. J Bus Res 122:685-699. doi:https://doi.org/10.1016/j.jbusres.2020.01.017

5. Atalla TN, Gasim AA, Hunt LC (2018) Gasoline demand, pricing policy, and social welfare in Saudi Arabia: A quantitative analysis. J Energy policy 114:123-133. doi:https://doi.org/10.1016/j.enpol.2017.11.047

6. Bekun FV, Alola AA, Sarkodie SA (2019) Toward a sustainable environment: nexus between CO2 emissions, resource rent, renewable and nonrenewable energy in 16-EU countries. Sci Total Environ 657:1023-1029

7. Beniulytè D, Šeinauskienè B, Rūtelionè A (2020) Perceived influence of corporate social responsibility on consumer loyalty: the role of ethical ideology, Entrepreneurship and Sustainability Issues 8(1): 291-300. https://doi.org/10.9770/jesi.2020.8.1(20)

8. Bhuian SN, Sharma SK, Butt I, Ahmed ZU (2018) Antecedents and pro-environmental consumer behavior (PECB): The moderating role of religiosity. Journal of Consumer Marketing. doi:https://doi.org/10.1108/JCM-02-2017-2076

9. Bouman T, Steg L (2019) Motivating society-wide pro-environmental change. One Earth 1:27-30 
10. Chanchaichujit K, Holmes K, Dickinson S, Ramkissoon H (2018) An investigation of how user generated content influences place affect towards an unvisited destination. In Proceedings of the 8th Advances in Hospitality and Tourism Marketing and Management (Ahtmm) Conference, Bangkok, Thailand, 25-29 June ; p. 213

11. Cheng T-M, Wu HC (2015) How do environmental knowledge, environmental sensitivity, and place attachment affect environmentally responsible behavior? An integrated approach for sustainable island tourism. J Sustain Tour 23:557-576. https://doi.org/10.1080/09669582.2014.965177

12. De Groot JIM, Steg L (2009) Morality and prosocial behavior: The role of awareness, responsibility, and norms in the norm activation model. J Soc Psychol 149:425-449. https://doi.org/10.3200/SOCP.149.4.425-449

13. Delistavrou A, Tilikidou I, Krystallis A (2021) Nested relationships in pro-environmental purchasing: $A$ moderated mediation model. Journal of Consumer Behaviour. doi:https://doi.org/10.1002/cb.1958

14. Doran R, Larsen S (2015) The relative importance of social and personal norms in explaining intentions to choose eco-friendly travel options. Int J Tour Res 18:159-166

15. EPA (2019) Inventory of US greenhouse gas emissions and sinks. http://www.epa. gov/ghgemissions/inventory-us-greenhouse-gas-emissions-and-sinks. Accessed 28 Sept 2019

16. Fielding KS, Mcdonald R, Louis WR (2008) Theory of planned behaviour, identity and intentions to engage in environmental activism. J Environ Psychol 28:318-326. https://doi.org/10.1016/j.jenvp.2008.03.003

17. Geiger SM, Fischer D, Schrader U (2018) Measuring what matters in sustainable consumption: An integrative framework for the selection of relevant behaviors. Sustain Dev 26:18-33. https://doi.org/10.1002/sd.1688

18. Gonand F, Hasanov FJ, Hunt L (2019) Estimating the impact of energy price reform on Saudi Arabian intergenerational welfare using the MEGIR-SA model. Energy J 40(3):101-123

19. Government of Saudi Arabia (2019) KSA Vision 2030: strategic objectives and vision realization programs. https://vision2030.gov.sa/sites/default/files/report/ Vision\%20Realization\%20Programs\%200verview.pdf. Accessed 01 Sept 2019

20. Huang $\mathrm{H}$ (2016) Media use, environmental beliefs, self-efficacy, and pro-environmental behavior. J Bus Res 69:2206-2212. https://doi.org/10.1016/j.jbusres.2015.12.031

21. Janmaimool P, Denpaiboon C (2016) Evaluating determinants of rural Villagers' engagement in conservation and waste management behaviors based on integrated conceptual framework of Proenvironmental behavior. Life Sci Soc Policy 12:12. https://doi.org/10.1186/s40504-016-0045-3

22. Janmaimool P, Denpaiboon $C$ (2016) Evaluating determinants of rural Villagers' engagement in conservation and waste management behaviors based on integrated conceptual framework of Proenvironmental behavior. Life Sci Soc Policy 12:1-20. https://doi.org/10.1186/s40504-016-0045-3

23. Johnston JE, Lim E, Roh H (2019) Impact of upstream oil extraction and environmental public health. Sci Total Environ 657:187-199 
24. Kagawa S, Goto Y, Suh S Accounting for Changes in Automobile Gasoline Consumption in Japan: 2000-2007. Economic Structures 1, 9 et al (2012) https://doi.org/10.1186/2193-2409-1-9

25. KAPSARC (2019) Policy pathways to meet Saudi Arabia's contribution to the Paris agreement. https://www.kapsarc.org/research/publications/policy-pathways-tomeet-Saudi-Arabia's-contributionto-the-Paris-agreement/ Accessed 27 Aug 2019

26. Kollmuss A, Agyeman J (2002) Mind the Gap: Why do people act environmentally and what are the barriers to pro-environmental behavior? Environ. Educ Res 8:239-260. https://doi.org/10.1080/13504620220145401

27. Maki A, Carrico AR, Raimi KT, Truelove HB, Araujo B, Yeung KL (2019) Meta-analysis of proenvironmental behaviour spillover. Nat Sustain 2:307-315. https://doi.org/10.1038/s41893-0190263-9

28. Mazzoni F (2020) Circular economy and eco-innovation in Italian industrial clusters. Best practices from Prato textile cluster. Insights Reg Dev 2:661-676. https://doi.org/10.9770/IRD.2020.2.3(4)

29. MEP (2015a) Data Tables from the Annual Reports. Saudi Ministry of Economy and Planning. Saudi Arabia

30. Nasir MA, Al-Emadi AA, Shahbaz M, Hammoudeh S (2019) Importance of oil shocks and the GCC macro economy: a structural VAR analysis. Resour Policy 61:166-179

31. Nunnally JC (1978) Psychometric theory. McGrawHill, New York, NY

32. Onel N (2016) Pro-environmental purchasing behavior of consumers. Soc Mark Q 23:103-121. https://doi.org/10.1177/1524500416672440

33. Parry IWH, Heine D, Lis E, Li S (2014) Getting Energy Prices Right: From Principle to Practice. International Monetary Fund

34. Quoquab F, Mohammad J (2020) Cognitive, affective and conative domains of sustainable consumption: Scale development and validation using confirmatory composite analysis. Sustainability 12:7784. https://doi.org/10.3390/su12187784

35. Rebecca George (2014) Saudi Arabia uses largest amount of crude oil for power generation since 2010. U.S. Energy Information Administration. https://www.eia.gov/todayinenergy/detail.php? id=18111\#

36. Rebecca George and Emily (2019) Saudi Arabia used less crude oil for power generation in 2018. U.S. Energy Information Administration. https://www.eia.gov/todayinenergy/detail.php?id=39693

37. Roberts G, Barbier E, Veld K (2019) Global emissions from crude oil: the effect of oil-deposit heterogeneity. Energy Policy 132:654-664

38. Roy EA (2013) Cognitive factors. Encyclopedia of Behavioral Medicine. Springer, New York, NY, USA, pp 447-448

39. Schwartz SH (2012) An Overview of the Schwartz Theory of Basic Values. Online Readings in Psychology and Culture 2(1). https://doi.org/10.9707/2307-0919.1116 
40. Schwartz SH (2012) An overview of the schwartz theory of basic values. Online Read Psychol Cult 2:11

41. Steg L, Bolderdijk JW, Keizer K, Perlaviciute G (2014) An integrated framework for encouraging proenvironmental behaviour: The role of values, situational factors and goals. J Environ Psychol 38:104-115. https://doi.org/10.1016/j.jenvp.2014.01.002

42. Tanner C, Kast SW (2003) Promoting sustainable consumption: Determinants of green purchases by Swiss consumers. Psychol Mark 20:883-902. https://doi.org/10.1002/mar.10101

43. Ture RS, Ganesh M (2014) Understanding pro-environmental behaviours at workplace: Proposal of a model. Asia Pac J Manag Res Innov 10:137-145. https://doi.org/10.1177/2319510X14536219

44. U.S. Energy Information Administration ( (2014) ). Global growth in use of gasoline outpaces diesel in 2014. https://www.eia.gov/petroleum/weekly/archive/2014/140730/twipprint.html

45. Ugulu I; Sahin M, Baslar S (2013) High school students' environmental attitude: Scale development and validation. Int J Educ Sci 5:415-424. https://doi.org/10.1080/09751122.2013.11890103

46. UNEP/UNESCO (2001) Is the Future Yours? Research Project on Youth and Sustainable Consumption

47. Van Der Werff E, Steg L, Keizer K (2013) The value of environmental self-identity: The relationship between biospheric values, environmental self-identity and environmental preferences, intentions and behaviour. J Environ Psychol 34:55-63. https://doi.org/10.1016/j.jenvp.2012.12.006

48. Wang P, Liu Q, Qi Y (2014) Factors influencing sustainable consumption behaviors: A survey of the rural residents in China. J Clean Prod 63:152-165. https://doi.org/10.1016/j.jclepro.2013.05.007

49. Yang S, Li L, Zhang J (2018) Understanding Consumers' Sustainable Consumption Intention at China's Double-11 Online Shopping Festival: An Extended Theory of Planned Behavior Model. Sustainability 10, 1801. https://doi.org/10.3390/su10061801

\section{Figures}

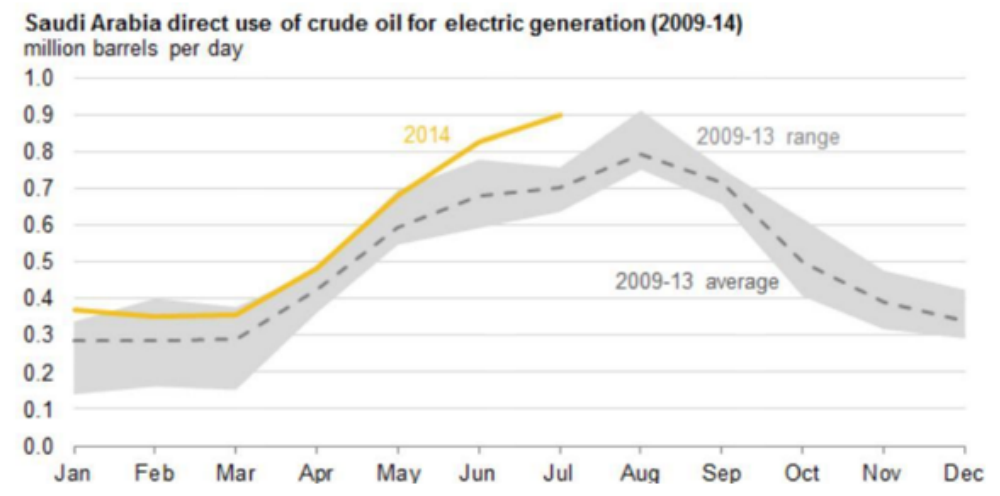

Saudi Arabia used less crude oil for power generation in 2018

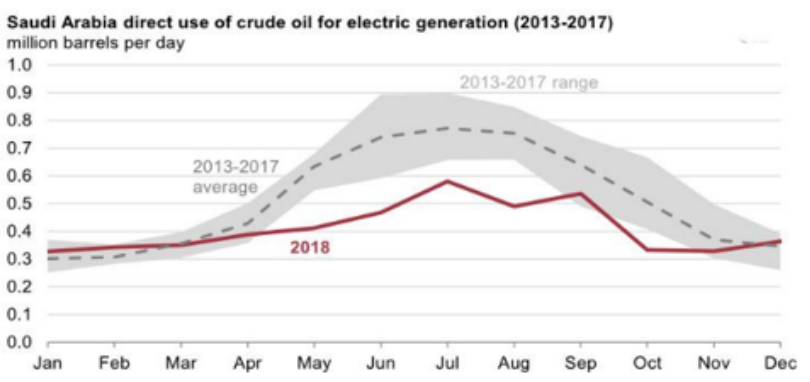

\section{Figure 1}

Crude oil consumption from 2009 - 2018 


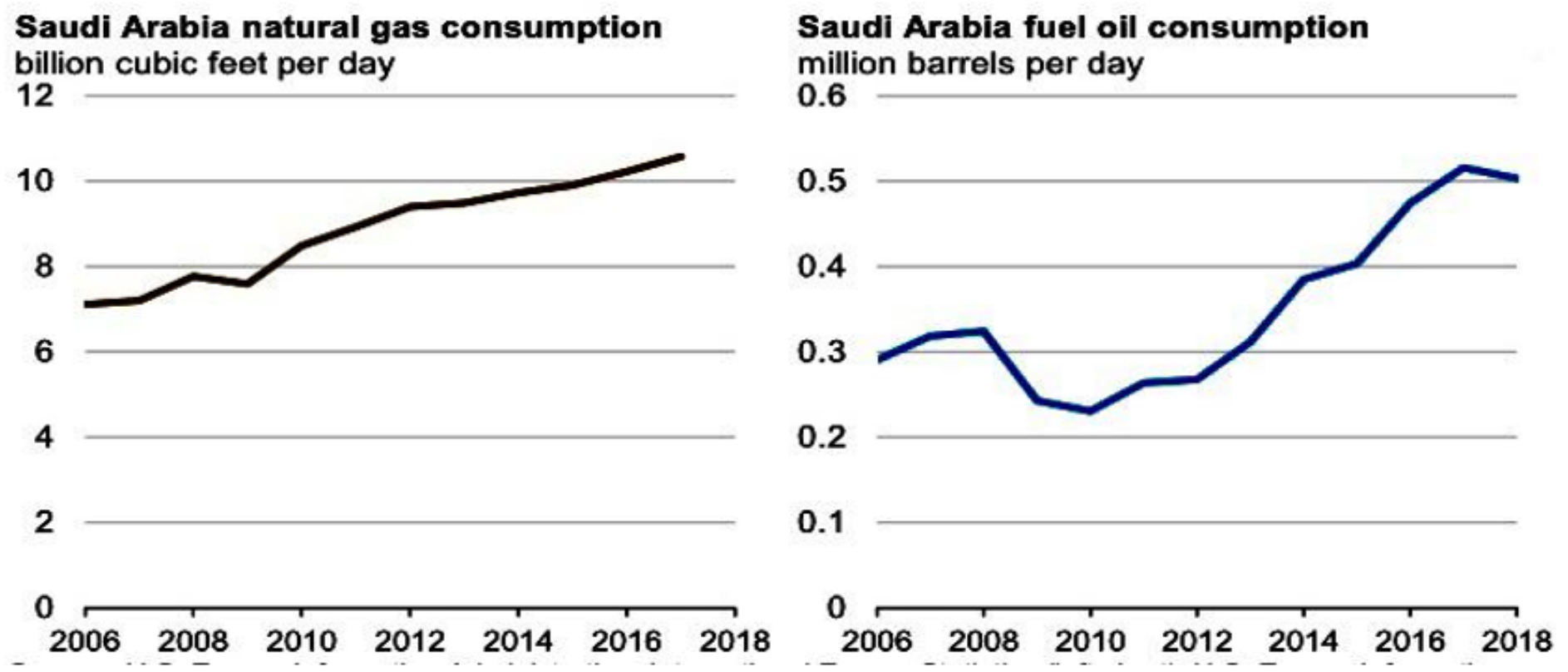

Figure 2

Comparative consumption of oil and natural gases

Source: U.S. Energy Information Administration

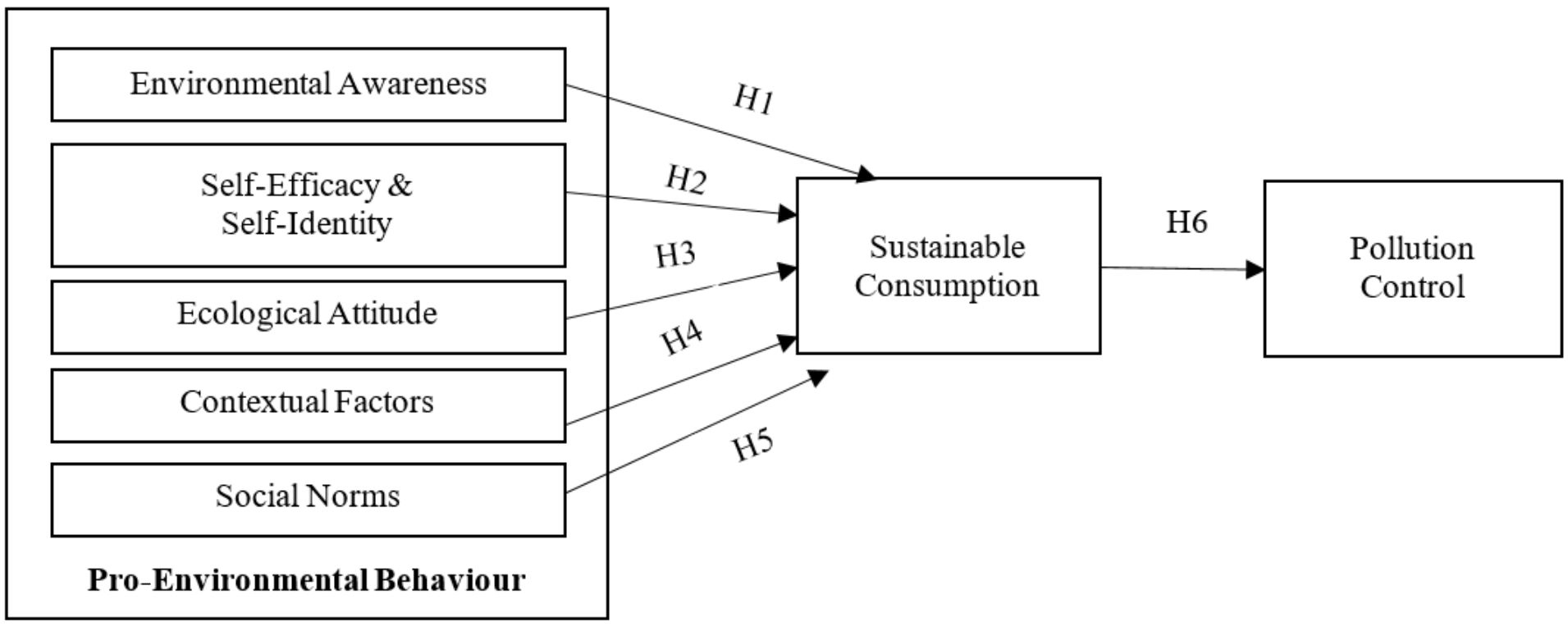

Figure 3 
Conceptual framework of pro-environmental behavior, sustainable consumption and pollution 